\title{
Catholic Social Doctrine and Economic Policy in Western Europe
}

\author{
Ksenia Chilkina ${ }^{1}$, Natalia Dorodonova ${ }^{1 *}$
}

\author{
${ }^{1}$ Saratov State Law Academy, Saratov, Russia \\ *Email:dorodonovan@gmail.com
}

\begin{abstract}
The social doctrine of the Catholic Church is a system that is open and capable of responding to new socio-economic challenges and ways of overcoming them. The necessary function of the state is to balance the interests of employers and employees and to assist those who are not covered by social security. This research gives a historical interpretation of the Catholic social teaching in the economic, labor, and social sphere. It is based on scientific literature and theoretical sources, Catholic Church encyclicals. The study analyzes the impact of the Catholic social doctrine on social and economic policy in Western Europe. This research could be useful in promoting reforms that shape a new global economic order and in creating a good legal framework for the welfare state. It is concluded that the Catholic Church has identified certain principles that are necessary to promote public welfare, namely, dignity, participation, subsidiarity, solidarity.
\end{abstract}

Keywords: Roman Catholic Church, Encyclical, History of state and law, European countries, Corporate social responsibility, Social justice, Economic and labor relations, Social Catholicism.

\section{INTRODUCTION}

Western civilization is currently experiencing a crisis generated from the inside and the outside. Social, economic, and political transformations of a considerable scale from the inside had tremendous pressure on traditional legal institutions and legal values in almost all Western countries.

The process of development of new economic systems and industrialization led to changes in the construction of social relations between the state and the individual in the European countries. Catholic scientists hoped to control and limit the destructive effects of industrialization. The decision, contrary to socialist theories, they saw not in radical redistribution of property rights or distribution of resources. Catholics hoped to create institutions that would help people naturally form "fair" socio-economic relations. The generally accepted position of the Catholic socialist economists was that collective actions are necessary to develop a system of rules that can lead economic interactions in line with the criteria for social justice.
The first theoretical work on developing a new economic and political position is the contradictory development of the unitary position of social Catholicism in the face of new problems delivered by the industrial society. There are many reasons for such inhomogeneity. First, it was preliminary theoretical work. Secondly, the views of the social class to which they belonged to the authors were primarily influenced. Bourgeois, as Italian priests Antonio Rosmini and Giuseppe Toniolo, expressed liberal and conservative views. Aristocrats like French legitimist Jean-Paul Villeneuve-Bargemon, Italian Catholic scientist Luigi Taparelli, and German Catholic bishop Wilhelm von Ketteler, French social reformer René de La Tour du Pin, and German social reformer Karl von Vogelsang expressed progressive views.

Social Catholicism, born in opposition to a liberal society, which arose due to the industrial revolution, became the basis of the Catholic social doctrine.

In the Christian Church teachings, the state is considered as one of the social institutions. In the 19-th century, during bourgeois revolutions, many European 
countries claimed superiority over the Church in the regulation of social relations; the Roman Catholic Church continued to provide help to people, at the same time forming an active social and political position. This view is reflected in the Catholic Church's social doctrine, in encyclicals such as "Rerum Novarum" (1891) of Leo XIII [1], "Populorum Progressio" (1967) of Paul VI [2].

A unique role in the formation of social doctrine should undoubtedly be given to "Rerum Novarum", the first document, playing a crucial role and becoming the doctrinal paradigm to which other encyclicals were subsequently attributed. The purpose of the state is to take care of the public and private good.

Catholic social economics is based on human rights and principles of Catholic social teaching that address the human need and transform mainstream economics with its reliance on individualism into personalist economics with its emphasis on personalism.

The fundamental category based on which the Catholic Church came to formulate its vision of the "welfare state" and developed its proposals is the category of "social justice". Because of this, the social doctrine has taken on an essential role from the very beginning. The object of social justice is the unconditional good of everyone, as it is directed to the common good and indirectly to the good of each individual. Social well-being is an indicator of interaction between the individual and the government, the individual and the state.

\section{RESEARCH METHODS}

The main method of research is the general scientific system-structural approach, due to which the relations existing between the state and the church in the social and economic field are considered a single system complex of legal and organizational means. Among the private law methods, comparative-legal, historical and formal legal methods are also used.

The specific objectives and goals of the work are achieved with various scientific methodologies, which allowed identifying and providing the main directions of the study. The analytical and historical methods help to determine the relations between Western states and the Roman Catholic Church in the social sphere. In the process of research, the authors rely on the sociological type of law understanding, the communicative concept of law.

\section{DISCUSSION}

There are quite a lot of studies related to Catholic social thought. This research provides a historical interpretation of Catholic social teaching in the social and economic sphere. Corporatism and Catholic social teaching usually inspired social policy. This research shows how Catholic teaching has carried out extensive and continuous actions to arrange economic and social development in the western world.

Catholic social doctrine attempts to study the relationship between economic and social development [3]. Attempts to propose an alternative economic system have been replaced by ethical criticism of the existing economic system in states. The revision of the doctrine of the Catholic Church on economics is associated with the policy of social Catholicism by including economic activity in the field of Christian action. The changes that have taken place in economics itself had also played a positive role. Nowadays the achieved rate of economic growth mitigates significantly social contradictions and there an opportunity arises for the development of improved social policy [4].

Catholic social teaching does not offer ready-made solutions to specific social problems. However, it provides an incentive to develop concrete proposals. In this respect, the principles of solidarity and subsidiarity give rise to reflection in social, economic, and political life. In Europe, corporatism and Catholic social teaching usually inspired social policy. However, the Church does not offer specific options for organizing economics. The social function of economics is very important from the point of view of the Catholic Church. The social nature of economics is that economic activity fulfills an important role in bringing people together. Church believes that labor involves a person in social life [5].

Economic activity also hands down traditions, social and moral principles. Besides social life makes a person think of collective welfare, to sacrifice private interests; this contributes to moral perfection. The church does not consider its social and economic doctrine universal but historical [6].

Social corporatism has a long history that can be traced back to the 19-th century when certain currents of political Catholicism were critical of the liberal order and the legacy of the French Revolution. The counterrevolutionary Catholic circles in France and Germany originated the corporate idea, which was to build a society by reviving legally recognized trade organizations around which social order and harmony could be achieved $[7,8]$. In these countries, the first trial regulation of the labor market was not initiated by socialists or liberals in national assemblies but by social Catholics. 19th-century entrepreneurs Leon Harmel and Franz Brandts played an essential role in forming Catholic social thought. In France, Léon Harmel helped his workers establish an insurance and hospital fund. Franz Brandts and Wilhelm von Kettler exercised religious leadership over the foundations in Germany. In the 19th century, the Roman Catholic Church was forced under the new conditions of church and state 
autonomy, freedom of religion, to seek ways of dialogue with the outside world, to analyze social problems, and propose its own vision of their solutions. The new principles of involvement in the process of supporting and protecting human life are set forth in the social teaching of the Catholic Church, the origin of which is associated with Pope Leo XIII.

In the 20th century, the new ideological direction of the Catholic Church social doctrine was emphasized, which focused on the process of maintaining socioeconomic and labor relationships where human dignity and rights would be ensured. The Second Vatican Council declared human rights to be not only a key element of Catholic Church teaching but also a common goal of interaction between numerous religious confessions, as well as between church and state. This meaning of human rights in the Catholic Church social teaching keeps to the present day. In "Quadragesimo Anno” (1931) Pope Pius XI emphasized: “...the more perfectly a graduated order is kept among the various associations, in observance of the principle of "subsidiary function," the stronger social authority and effectiveness will be the happier and more prosperous the condition of the State" [9]. In "Caritas in Veritate" (2009) Pope Benedict XVI called for: “...reviewing their internal social assistance and welfare policies, applying the principle of subsidiarity and creating better integrated welfare systems, with the active participation of private individuals and civil society" [10].

Thus, the Roman Catholic Church has also devoted much attention to identifying the nature and causes of the global financial and economic crises and developing measures to prevent them. Besides, it continues to cooperate with the state in ensuring human social rights, maintaining a certain material standard of living and human dignity. The European Commission strategy on CSR states that the government and the companies, trade unions, and civil society have to find new forms of corporate responsibility.

The Catholic social and economic teachings are determined by their historical relevance and not only by recognizing their theoretical veracity [11]. It allows social Catholicism to adjust its position without compromising its public image. On this basis, the Catholic Church rejects any abstract models and abstract methods of social reality analysis. In particular, the Church itself does not try to shape any social security and economic model, though this position is more characteristic of a modern doctrine. The perception of economics as a part of society determines the features of economic views of social Catholicism, which are expressed by the fact that the task of economic activity of a person is not considered in a narrow specialized aspect. Economic activity is not seen as a separate type of human behavior that is subject only to economic goals (as it is done in a modern economic theory) [12].
Due to this approach, the evaluation of economic activity by the Catholic Church is not limited to the analysis of economic results, but primarily it takes into account any impact on human capital development.

\section{CONCLUSION}

Nowadays the social, economic, and labor legislation can already be classified as traditional branches, where the experience and opinion of the Church are taken into account in lawmaking activities in the European Union. In the conditions of rapid economic development, the participants of the legislative process involve church representatives as experts in drafting legislation. The Catholic Church proposes a conception of specific economic categories and economic relations so that society could respond to challenges based on its teaching. Gradually the Catholic Church has identified certain principles necessary to promote public welfare, namely dignity of the human person, participation, subsidiarity, solidarity. The legal and practical concept of society has forced the Catholic doctrine to focus on social and economic institutional changes.

\section{ACKNOWLEDGMENTS}

The reported study was funded by RFBR, project number 20-011-00673 "The influence of social doctrine of the Roman Catholic Church on European social legislation development in the XIX-XX centuries".

\section{REFERENCES}

[1] Leo XIII, Rerum Novarum, 1891. Retrieved from https://www.vatican.va/content/leoxiii/en/encyclicals/documents/hf 1xiii_enc_15051891_rerum-novarum.html

[2] Paul VI, Populorum Progressio, 1967. Retrieved from https://www.vatican.va/content/paulvi/en/encyclicals/documents/hf_pvi enc 26031967 populorum.html

[3] J. Holland, Theological economy, Catholic social teaching and human flourishing. Journal of Futures Studies 24(3) (2020) 37-49. Retrieved from https://jfsdigital.org/articles-and-essays/vol-24-no3-march-2020/10750-2/

[4] J. Backhaus, G. Chaloupek, H. Frambach, On the Economic Significance of the Catholic Social Doctrine: 125 Years of Rerum Novarum, Cham: Springer, 2017, $190 \mathrm{p}$.

[5] S.P. Barrows, Labor economics and the development of papal social encyclicals, Journal of Markets \& Morality 14(1) (2011) 7-22. 
[6] M.G. Nixon, The economic foundations of modern Catholic social teaching: Past and prospect, ETD Collection for Fordham University, 2013. Retrieved from https://fordham.bepress.com/dissertations/AAI361 1876M.

[7] N.V. Dorodonova, K.V. Chilkina, Role of the Catholic Church in the Formation of International Organizations in the Protection and Implementation of Social Human Rights (first third XX century). Saratov State Law Academy Bulletin, 4(135) (2020) 29-38. DOI: https://doi.org/10.24411/2227-7315-2020-10097

[8] J. Defourny, M. Nyssens, Social enterprise in Europe: At the crossroads of market, public policies and third sector. Policy and Society, 29, 2010, 231-242. DOI: https://doi.org/10.1016/j.polsoc.2010.07.002

[9] Pius XI, Quadragesimo Anno, 1931. Retrieved from: $\quad$ https://www.vatican.va/content/piusxi/en/encyclicals/documents/hf $\mathrm{p}$ xi_enc_19310515_quadragesimo-anno.html

[10] Benedict XVI, Caritas in Veritate, 2009. Retrieved from: https://www.vatican.va/content/benedictxvi/en/encyclicals/documents/hf_benxvi_enc_20090629_caritas-in-veritate.html

[11] A.M. Baggio, Lavoro e dottrina sociale Cristiana: Dalle origini al Novecento, Roma: Città Nuova, 2005, 248 p.

[12] A. Shadle, Interrupting Capitalism: Catholic Social Thought and the Economy, Oxford University Press, 2018, 392 p. 